Acta vet. scand. 1987, 28, 1-8.

From the Department of Applied Zoology, University of Kuopio, the Department of Surgery, College of Veterinary Medicine, Helsinki, and the Department of Obstetrics and Gynaecology, College of Veterinary Medicine, Hautjärvi, Finland.

\title{
Autosomal Trisomy in a Heifer
}

\author{
By Auli Mäkinen, Ilkka Alitalo and Matti Alanko
}

\begin{abstract}
Mäkinen, Auli, Ilkka Alitalo and Matti Alanko: Autosomal Trisomy in a Heifer. Acta vet. scand. 1987, 28, 1-8. - A malformed Ayrshire heifer had one additional autosome in all the lymphocyte metaphases studied. Chromosome banding techniques showed the karyotype of the calf to be $2 n=61, X X,+24$.

Slight prognathia of the lower jaw and peculiar abbrevations in the structure of the genitals were the most apparent anomalies, in addition to heart abnormalities, a poorly-closed urachus and slow growth rate.

autosomal trisomy; congenital malformations; chromosome banding analysis.
\end{abstract}

\section{Introduction \\ Evidence that chromosome alterations cause developmental defects in cattle is sparse. Cytogenetic studies of abnormal phenotypes in cattle are few compared with humans (Alberman \& Creasy 1977, Fechheimer 1979, Gustavsson 1980a, Chandley 1981, Rieck 1984). \\ The development of chromosome banding techniques in 1970 (Gustavsson 1980b) has helped resolve the role of chromosome alter- nations in congenital abnormalities in cattle.}

\section{Material and methods}

A female Ayrshire calf from a dairy farm in eastern Finland was remitted to the College of Veterinary Medicine by the local veterinarian, because of its small size and abnormal appearance. The weight of the calf was monitored weekly from the age of 7 months to 10 months. The tubular bones of the limbs and skull were radiographed at 7,9 and 12 months. Clinical examinations were made weekly. Monthly laboratory studies were made on blood; $\mathrm{Hb}, \mathrm{Hkr}$ and leucocyte counts were taken and serum ASAT, ALAT, AFOS and electrolytes were measured. The heifer died suddenly at the age of 12 months. A necropsy was performed. The genital organs were examined both macroscopically and histologically.

Blood samples for chromosome analysis were taken from both parents, a first-calving mother and an AI-bull, as well as from the calf.

The chromosomes were studied by the standard blood culture method of Gustavsson et al. (1983) and were identified by the GTG (Seabright 1971) and RBA (Dutrillaux et al. 1973) banding techniques. The amount and distribution of constitutive heterochromatin was analysed by the CBG technique of Sumner (1972).

The chromosomes were arranged into karyotypes according to the international standard karyotype for cattle (Proceeding of the 


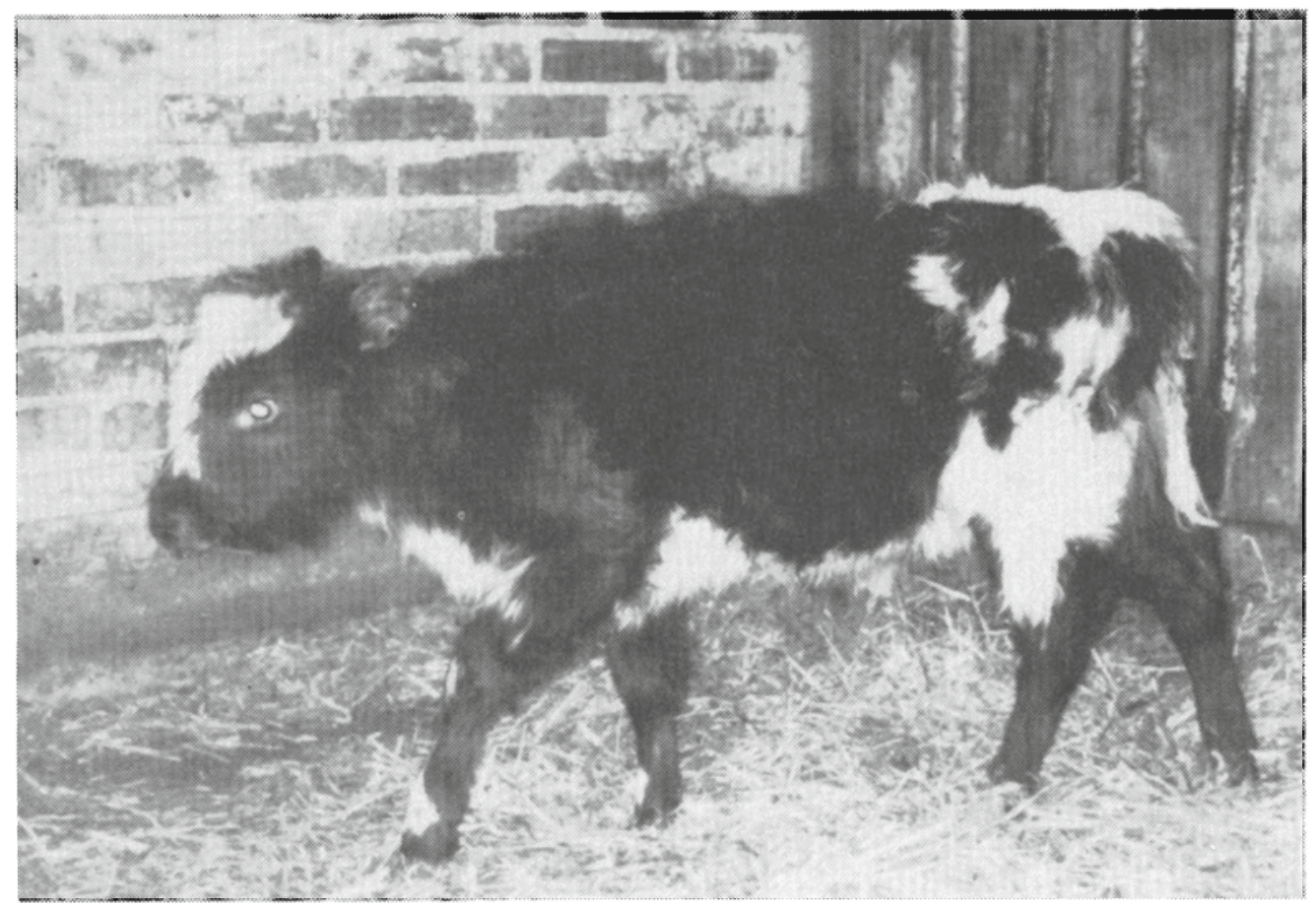

Figure 1. The trisomic calf at the age of 6 months.

First International Conference for the Standardization of Banded Karyotypes of Domestic Animals, Reading, England 1980). We also used the landmark system for GTGbanded chromosomes proposed by Lin et al. (1977) and followed the identifying features of RBA-banded chromosomes presented by Di Berardino \& Iannuzzi (1982) and Di Berardino et al. (1985).

\section{Results}

\section{Clinical findings}

The calf was small throughout its life compared with animals of the same age (Fig. 1). Its lower jaw was about $2 \mathrm{~cm}$ longer than the upper jaw (prognathia inferior). Its coat was long-haired and of poor quality during the first 5 months of life, but then became normal. The calf had a small umbilical hernia, which persisted through all its life. Growth rate is shown in Figure 4. At the age of 8 months symptoms of indigestion were noted; is showed mild tympany and signs of pain which were reversed by medication. The heifer died suddenly at the age of 12 months. Prior to death mild tympany and sluggishness were seen.

\section{Radiological findings}

Radiography failed to show any pathological condition either in the bones or in the growth cartilages. In the skull, the mandibular bone was longer than the maxillar bone as mentioned above. 


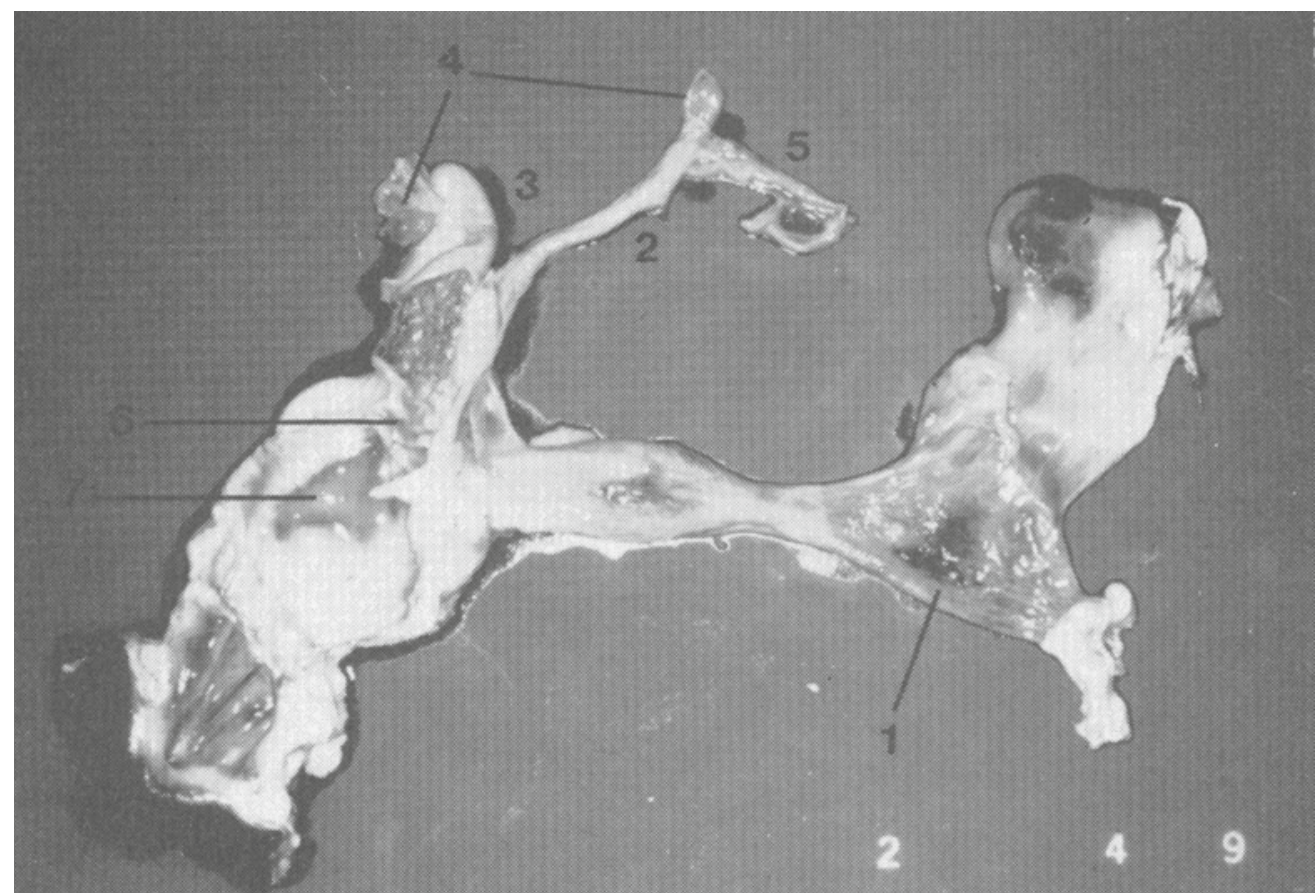

Figure 2. Urinary and genital tract of a heifer with autosomal trisomy. The urachus was partly open and the section concomitant to the urinary bladder was greatly distended with a very thin wall. This had ruptured about $5 \mathrm{~cm}$ away from the urinary bladder (1). The right uterine horn (2) was only a rudimentary cord of connective tissue. The left uterine horn (3) was short but normal in shape and structure. Ovaries (4), right oviduct (5), poorly developed cervix (6), distended vagine (7).

\section{Laboratory findings}

The blood haemoglobin value varied between 8.4 and $8.7 \mathrm{~g} / 100 \mathrm{ml}$ and the hematocrit value was $27-28 \%$. All other laboratory parameters corresponded to the reference values.

\section{Necropsy findings and gynaecological examination}

The heart. The only pathological finding outside the urinary and genital tract was in the heart, where a persistent foramen ovale and an incomplete interventricular septum were seen.
Urinary tract. The urachus was partly open and the section concomitant to the urinary bladder was greatly distended with a very thin wall. This had ruptured about 5 $\mathrm{cm}$ away from the urinary bladder (Fig. 2). The rupture hole was $3 \mathrm{~cm}$ in diameter. About 10 litres of urinous liquid were found in the abdominal cavity thus making clear the sudden death of the heifer.

Genital organs (Fig. 2). The vagina was short but greatly distended, especially at the cervical end. The cervix was poorly developed with a thin but complete cervical canal 
of normal patency. The right uterine horn was only a rudimentary cord of connective tissue. The adjacent tube was of almost normal appearance but small and flaccid. The right ovary was small and rudimentary with two small follicles, 0,4 and $0,6 \mathrm{~cm}$. The left uterine horn was short $(12 \mathrm{~cm})$ but normal in shape and structure. Histology showed an atrophic mucosa with small rudimentary uterine glands. The left uterine tube was missing, only a thin connective tissue cord represented the tubal rudiments. The left ovary was about $1 \times 1.5 \mathrm{~cm}$ in size. It had one visible follicle, $0.9 \mathrm{~cm}$ in diameter. Histology showed that there were also several small, atretic follicles.

\section{Chromosome studies}

The chromosomes were analysed with GTG and RBA banding techniques and in all the lymphocytes studied, the $2 \mathrm{n}=61$, XX chromosome complement was found. The extra chromosome was a small autosome, number 24 . Hence, the calf had a $2 n=61, X X+24$ karyotype (Fig. 3). The constitutive heterochromatin identified by CBG staining was constant; the centromeric regions of the acrocentric autosomes were darkly stained and the submetacentric $\mathrm{X}$ chromosomes had no clear banding patterns.

Both parents had normal cattle karyotypes. Hence, the trisomy was established as a de novo chromosome rearrangement.

The trisomic calf was the first offspring of the 2-year-old female parent. The gestation age was normal. The male parent had no record of malformed progeny.

The birth weight of the calf is unknown, but it was considerably smaller than normal Ayrshire female calves.

\section{Discussion}

Disorders of segregation (non-disjunction) in the course of gametogenesis in either of the parents or in the somatic cells can cause trisomy or monosomy in the resulting primary products (Jacobs \& Morton 1977). Chromosomal aneuploidy is more common in prenatal than in postnatal stages, autosomal trisomies tending to survive longer than monosomic ones (Carr 1971). In domestic animals, most autosomal monosomies and trisomies are probably eliminated prior to embryo implantation (Hare et al. 1980, King et al. 1980, Popescu 1980, King et al. 1981) but occasionally autosomal trisomies occur postnatally. They are then associated with malformations. The first report in humans was of an association between trisomy 21 and the Down syndrome by $L e$ jeune et al. in 1959.

The first case of autosomal trisomy in cattle was found by Herzog \& Höhn in 1968 in a calf which had morphological malformations, brachygnathia inferior and ascites congenitus. They used conventional chromosome staining and suggested that the trisomic chromosome was either number 17 or 18.

Mori et al. (1969) investigated an autosomal trisomy in a malformed newborn male calf with several phenotypic anomalies. Gluhovschi \& Bistriceanu (1970) reported nanismus in association with trisomy in three calves. They suggested that the trisomic chromosome was number 23 with conventional chromosome staining. Dunn \& Johnston (1972) found one trisomic male calf. The chromosomal defect was associated with extreme brachygnathia inferior. The extra chromosome was assumed to be a large autosome in nonbanded metaphases.

Höhn \& Herzog (1970), Herzog \& Höhn (1971), Herzog (1974) and Herzog et al. (1977) reported a further 16 cases of calves with brachygnathia inferior and other malformations. The trisomic autosome number was found to be 17 with chromosome ban- 


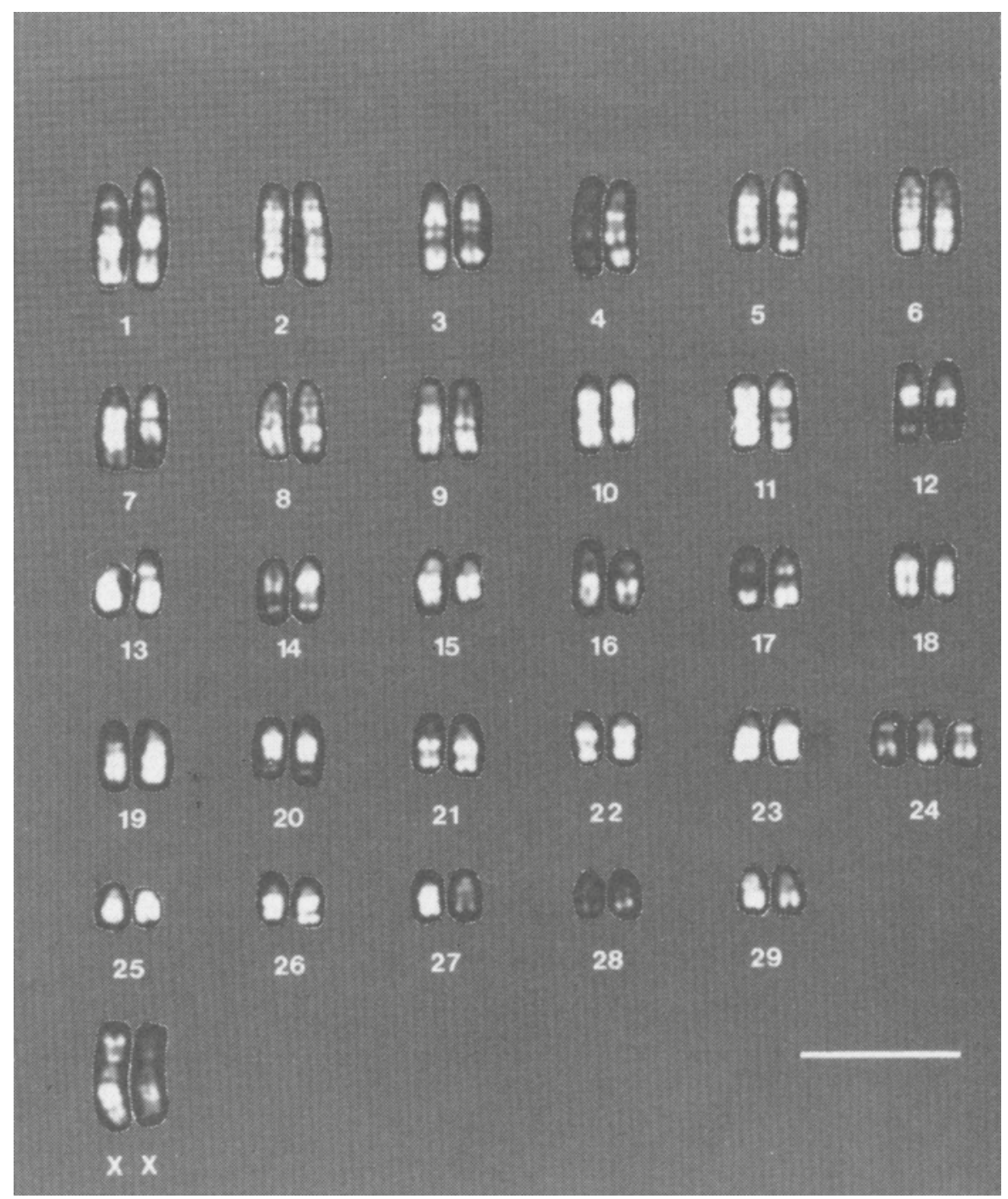

Figure 3. The RBA banded karyotype of the trisomic female calf, $2 \mathrm{n}=61, \mathrm{XX},+24$. - Scale is $10 \mu$.

ding analysis. Tschudi et al. in 1975 reported autosomal trisomy, $61, \mathrm{XX},+?(13-18)$ in a calf with an incomplete interventricular septum, patent foramen ovale and umbilical hernia; in 1977 they found the same chromosomal aneuploidy in another calf with reduced viability. The chromosomes were analysed with conventional chromosome staining. Gluhovschi et al. (1975) described a number of calves as trisomic, $61, \mathrm{XX}$ or $61,+23$ with a form of dwarfism characterized by short legs, reduced growth rate, de- 


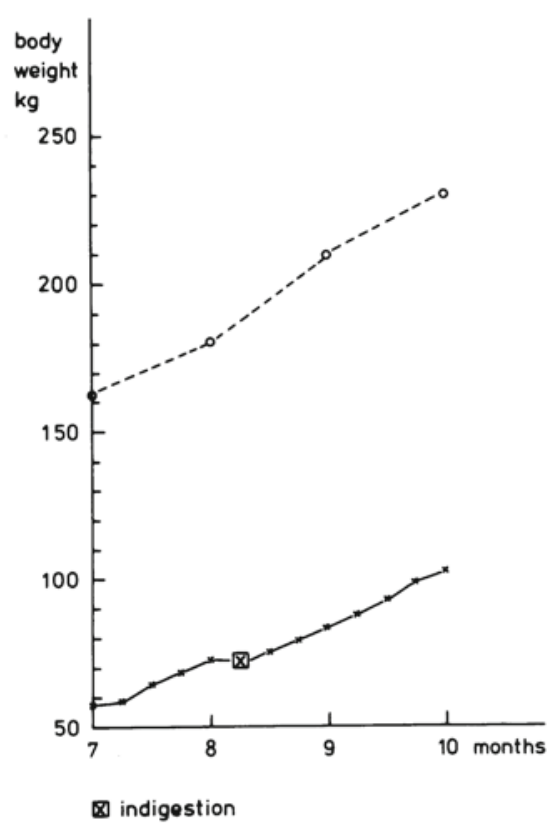

Figure 4. Growth of the trisomic calf $(x-x)$ from the age of 7 months to 10 months compared to the normal female Ayrshire calves growth (O- - - ) (Ettala \& Ruohomäki 1980). At the age of 8 months symptoms of indigestion were noted in trisomic calf.

layed puberty and abnormalities in the appearance of the optic papillae associated with the arrangement of the retinal vessels.

A trisomy of chromosome number 18 in a mosaic structure $61, \mathrm{XY},+18 / 60, \mathrm{XY}$ was detected with chromosome banding in one male calf with dwarfism and other malformations (Herzog et al. 1982). The $2 \mathrm{n}=61$, $\mathrm{XY},+18$ chromosome complement occurred in $20 \%$ of the lymphocytes studied. Mayr et al. (1985) found a female calf trisomic for chromosome number 22. This calf had an umbilical hernia, an urachal fistula and slight brachygnathia. This trisomy was not associated with lethality. The chromosomes were examined with banding methods.
Autosomal trisomy is thus frequently associated with congenital anomalies and growth retardation. In our case the pathological findings were somewhat different from previously described ones, with slight prognathia of the lower jaw and peculiar abbrevations in the structure of genitals. The heart abnormalities, poorly-closed urachus and slow growth rate, which we also found, seem to be features common to several autosomal trisomies. The viability of the affected individuals varies according to the severity of the lesions in the important organs, such as the heart, the urinary tract or the urachus.

\section{Acknowledgements}

We are grateful to veterinarian Eero Remes for his kind cooperation in referring the calf of the present study. We would also like to thank Tarja Väisänen for her excellent laboratory assistance, Dr. Henni Höhn for her interest in this study and Drs. Ingemar Gustavsson and Dino di Berardino for their comments on the karyotype.

\section{References}

Alberman E, Creasy MR: Frequency of chromosomal abnormalities in miscarriers and perinatal death. J. Med. Genet. 1977, 14, 313 -315 .

Carr DH: Genetic basis of abortation. Annu. Rev. genet. 1971, 5, 65-80.

Chandley AC: The origin of chromosomal aberrations in man and their potential for survival and reproduction an the adult human population. Ann. Génét. 1981, 24, 5-11.

Di Berardino D, Iannuzzi L: Detailed description of R-banded bovine chromosomes. J. Hered. 1982, 73, 434-438.

Di Berardino D, Iannuzzi L, Lioi MB: The high-resolution RBA-banding pattern of bovine chromosomes. Cytogenet. Cell Genet. 1985, 39, 136-139.

Dunn HO, Johnson RH Jr: A $61 \mathrm{XY}$ cell line in a calf with extreme brachygnathia. J. Dairy Sci. 1972, 55, 524-526.

Dutrillaux B, Laurent C, Couturier J, Lejeune 
$J$ : Coloration des chromosomes humains par l'acridine orange aprés traitement par le 5 bromodeoxyuridine. (Acridine orange staining method in human chromosomes treated with 5 bromodeoxyuridine). C. R. Acad. Sc. (Paris) 1973, 276, 3179-3181.

Ettala E, Ruohomäki H: Lypsykarjan pitkäaikaiskoe: Erirotuisten hiehojen kasvatulokset. (The growth rate in female calf of different breed). Maaseudun Tulevaisuus, Koetoiminta ja Käytänto 16.12.1980.

Fechheimer NS: Cytogenetics in animal production. J. Dairy Sci. 1979, 62, 844-853.

Gluhovschi $N$, Bistriceanu M: Untersuchungen zur Chromosomenpathologie in der Veterinärmedizin. (Veterinary medicine and cytogenetics). 1. europäisches Kolloquium über Zytogenetik in Veterinärmedizin und Säugetierkunde. Giessen 1970, in Giessener beitr. Erbpath. Zuchthyg. Sonderheft. 1970, 1, 93-100.

Gluhovschi $N$, Bistriceanu $M$, Palicica $R$ : Les troubles de la reproduction chez les animeaux domestiques dus à des modifications du genome. (Cytogenetic studies of domestic animals with reproductive problems). Cah. Méd. Vét. 1975, 44, 155-163.

Gustavsson I: Chromosome aberrations and their influence on the reproductive performance of domestic animals - a review. Z. Tierzüchtg. Züchtgsbiol. 1980a, 97, 176-195.

Gustavsson I: Banding techniques in chromosome analysis of domestic animals. Adv. Vet. Sci. Comp. Med. 1980b, 24, 245-289.

Gustavsson I, Settergren I, King WA: Occurrence of two different reciprocal translocations in the same litter of domestic pigs. Hereditas 1983, 99, 257-267.

Hare WCD, Singh EL, Betteridge KJ, Eaglesome MD, Randall GCB, Mitchell D, Bilton $R J$, Trounson $A O$ : Chromosomal analysis of 159 bovine embryos collected 12 to 18 days after estrus. Can. J. Genet. Cytol. 1980, 22, 615-626.

Herzog A: Autosomale Trisomie bei der letalen Brachygnatie des Rindes (bovines TrisomieBrachygnathia-syndrom). (Autosomal trisomy in cattle with brachygnathia inferior). Dtsch. Tierärztl. Wschr. 1974, 81, 77-100.
Herzog A, Höhn H: Autosomale Trisomie bei einem Kalb mit Brachygnathia inferior und Ascites congenitus. (Autosomal trisomy in a calf with Brachygnathia inferior and congenital edema). Dtsch. Tierärztl. Wschr. 1968, 75, 604-606.

Herzog A, Höhn H: Autosomale Trisomie bei der letalen Brachygnathie des Rindes. (Autosomal trisomy in cattle with lethal brachygnathia). Cytogenetics 1971, 10, 347-355.

Herzog A, Höhn H, Olyschläger $F$, Rusch $P$ : 17-Trisomie-Mosaik beim Rind. (17-trisomicmosaic cattle). Berl. Münch. Tierärztl. Wschr. 1982, 95, 352-354.

Herzog A, Höhn H, Rieck GW: Survey of recent situation of chromosome pathology in different breeds of german cattle. Ann. Génét. Sél. Anim. 1977, 9, 471-491.

Höhn H, Herzog A: Zwei weitere Fälle von autosomaler trisomie bei Kälbern mit Brachygnathia inferior und anderen Missbildungen. (Two additional cases of autosomal trisomy in calves with brachygnathia inferior and other anerrations). Giessener Beitr. Erbpath. Zuchthyg. 1970, 3, 1-7.

Jacobs PA, Morton NE: Origin of human trisomics and polyploids. Hum. Hered. 1977, 27, 59-72.

King WA, Linares $T$, Gustavsson I, Bane A: Presumptive translocation type in embryos sired by bulls heterozygous for the $1 / 29$ translocation. Hereditas 1980, 92, 167-169.

King WA, Linares T, Gustavsson I: Cytogenetics of preimplantation embryos sired by bulls heterozygous for the $1 / 29$ translocation. Hereditas 1981, 94, 219-224.

Lejeune $J$, Gautier $M$, Turpin $R$ : Etude des chromosomes somatiques de neuf enfants mongoliens. (Extra somatic chromosome in newborn with mongolism). C. R. Acad. Sci. 1959, 248, 1721-1722.

Lin CC, Newton DR, Church RB: Identification and nomenclature for G-banded bovine chromosomes. Can. J. Genet. Cytol. 1977, 19, 271-282.

Mayr B, Krutzler $H$, Auer $H$, Scheleger $W$, Sasshofer $K$, Glawischnig $E$ : A viable calf with trisomy 22. Cytogenet. Cell genet. 1985, 39, 77-79. 
Mori M, Sasaki M, Makino S, Ishikawa $T$, Kawata $K$ : Autosomal trisomy in a malformed newborn calf. Proc. Japan Acad. 1969, 45, 955-957.

Popescu CP: Cytogenetic study on embryos sired by a bull carrier of $1 / 29$ translocation. Proc. 4th Eur. Colloq. Cytogenet. Domest. Anim., Uppsala 1980, pp. 182-186.

Proceedings of the First International Conference for the Standardization of Banded Karyotypes of Domestic Animals. Reading, England. 1976. (Eds. Ford CE, Pollock DL \& Gustavsson I). Hereditas 1980, 92, 145-162.

Rieck GW: Veterinary medicine and cytogenetics. Proc. 6th Eur. Colloq. Cytogenet. Domest. Anim., Zürich 1984, pp. 20-34.

Seabright M: A rapid banding technique for human chromosomes. Lancet 1971, 2, 971972.

Sumner AT: A simple technique for demonstrating centrometric heterochromatin. Exp. Cell. Res. 1072, 75, 304-306.
Tschudi $P$, Ueltschi $G$, Martiq $J$, Küpfer $U$ : Autosomale Trisomie als Ursache eines hohen Ventrikel-septumdefekts bei einem Kalb der Simmentalerrasse. (Autosomal trisomy as the cause for defects of the interventricular septum in a Simmental calf). Schweiz. Arch. Tierheilkd. 1975, 117, 335-340.

Tschudi $P$, Zahner B, Küpfer $U$, Stämpfli $G$ : Chromosomenuntersuchungen an schweizerischen Rindermassen. (Chromosome investigation of Brown Swiss cattle). Schweiz. Arch. Tierheilkd. 1977, 119, 329-336.

\section{Sammanfattning}

Autosomal trisomi hos en kviga.

Hos en Ayrshire-kviga med långsam tillväxt och plötslig död i en ålder av 1 år kunde en extra autosomal kromosom påvisas $\mathrm{i}$ alla lymfocyter. Bandfärgning av kromosomerna visade karyotypen vara $2 \mathrm{n}=61, \mathrm{XX},+24$.

Kvigan hade en lindrig prognathia inferior, ett litet navelbrock samt utvecklingsstörningar i urogenitalsystemet och defekter i hjärtat.

(Received September 19, 1986).

Reprints may be requested from: Auli Mäkinen, Department of Applied Zoology, University of Kuopio, SF-70211 Kuopio, Finland. 